\title{
The Reliability and Validity of the Scale of Professional Problems Perception: A Research on Social Worker
}

\author{
Assistant Professor Dr. Erol Karaca (Corresponding author) \\ Anadolu University, Faculty of Health Sciences, Department of Social Work \\ 26470 Eskisehir/Turkey \\ E-mail: erolkaraca@anadolu.edu.tr/karacae69@hotmail.com \\ Professor Dr. Nuray Gökçek Karaca \\ Anadolu University, Faculty of Health Sciences, Department of Social Work \\ 26470 Eskisehir/Turkey \\ E-mail: ngokcek@anadolu.edu.tr/nuraygokcek9@gmail.com
}

\author{
Received: November 25, 2015 Accepted: January 1, 2016 Published: January 3, 2016 \\ doi:10.5296/ijsw.v3i1.8630 URL: http://dx.doi.org/10.5296/ijsw.v3i1.8630
}

\begin{abstract}
This study sought to develop a Likert type scale which is valid and reliable in order to investigate the professional problems of social workers. The research was carried out with 98 social workers, emypoled in Istanbul, Ankara, Izmir, Adana, Eskisehir, Trabzon, Samsun, Diyarbakir, Konya, Karaman, Kayseri, Aydin, Hatay, Elazig, Yozgat, Corum, Amasya, Yalova, Kutahya, Duzce, Bolu, Karabuk, Tekirdag, Sakarya provinces of Turkey, in 2014. The data was collected using a questionnaire consisting of two sections, developed to determine the social workers' professional problems. The first part contains demographic and personal information, consisting of items about the gender, age, marital status, status, managerial positions, the type of institution, provincial aspects, social work experience, branch, income level, satisfaction level of social work, income level sufficiency, future confidence perception, compatibility with the profession in terms of personal characteristics, perceptions of syndication. The second part includes 40 expressions related to professional problems of social workers on a 3-point Likert-type scale consisting of 3 choices, from $1=$ Disagree to 3 $=$ Strongly Agree. The accumulated data was analyzed with factor analysis by using SPSS.
\end{abstract}


The findings of the study revealed that the scale is valid and reliable. Results of the research show that regardless of their position, duty, rank or gender, social workers all concur on the fact that the rights provided them are insufficient and they run into problems that can be categorized as 'working conditions and social rights', 'working method', 'professional identity', 'professional execution conditions', 'employment and promotion policies', 'professional organization' and 'vocational integration'.

Keywords: Social work, Professional problems of social workers, Professional problem perception scale

\section{Introduction}

Social work is a dynamic and struggle based occupation that aims to prevent and resolve problems of individuals, families or societies that occur without their control in their living environment, to meet their material and immaterial needs and also to increase the social prosperity and the quality of life State Planning Organization (DPT), 2001: 11; United Nations (UN), 2003). Social work depends on its laborers - social workers- carrying out their occupations with efficiency and effectiveness to succeed in its goals. In this context, social workers need to have occupational aptitudes that their occupation requires. However, as much as social work depends on social workers having the aptitude to succeed, it also depends on the occupational conditions of this profession. Therefore, social workers, like other occupations, need to have an ideal "problem-free environment" in their occupations. Yet, when the literature was reviewed, it was seen that social work has ran into many problems due to the fact that social work is a newly emerging occupation category and it is exposed to many problems depending on developments, changes and transformation in social and health services, and it was also noted that these problems were categorized in very different ways (Işıkhan, 1998; Berkün, 2010; Altınöz, 2014; Ceylan, 2014)

According to Altınöz (2014), who defined the problems in the occupation of social work as problems relating to efficiency, production, organization, integration and work definition, these problems hinder the social work occupation and they inhibit new expansions. Also according to Altınöz (2014), the emergence of these problems in Turkey occurred due to lack of policies relating to social work occupation, the lack of effectiveness in production of occupational rights, lack of production of the knowledge that would nurture this occupation, lack of schools of thought and philosophies that would help expanding this occupation and also due to the fact that social services were bound to Social Services Child Protection Agency (SHÇEK) for so many years.

Ceylan (2014), used the scanning model in his research with 14 social workers, and based on the results; he emphasized the heavy workload and lack of cohesion between their training and their actual jobs were mainly caused due to lack of social workers versus surplus of applicants to the occupation, and added that social workers work contrary to ethics and responsibilities of the occupation. Similar to Ceylan, Berkün (2010) also stated in her work entitled "Occupational Hazards That Social Service Experts Run into in Their Work Life: Bursa Example" that social workers have heavy workloads. Workers such as Işıkhan (1998, 1999), Basım and Şeşen (2005) ran into stress factors in their daily work life and despite their level of exhaustion, their job satisfaction is very low. 
According to Bulut (2014) the most important problem for social workers is the problem of the "job/occupation title" and to solve this problem, the title "social service expert" must be used instead of the term "social worker".

C1lga (2004), in his work "Social Services Science and Occupation", emphasized that social workers feel various pressures heavily and due to the current order of the social work occupation he added that social workers are getting pinched by the pressure. Cilga mentions that this pincer forces work lives of the social workers into being torpid and nonproductive, and added that this situation also affects their socials lives; then he gives certain suggestions to social workers endurance for progress and let them free from the pressure:

- Creating dynamism for scientific and occupational forces, which is centered around strategies and policies that deal with the existing contradictions,

- Giving freedom to the individual and the society,

- Creating a democratic social order,

- Setting all occupational forces in motion towards certain common objectives,

- Producing scientific effort,

- Having education intuitions becoming leaders in university-private sector relationship,

- Achieving progress in education, raising the quality and standards in newly created departments, and getting rid of level discrepancies that exist between students trained in different departments.

The problems of social work and social workers prompted researches to elaborate the topic not only in Turkey, but also in many other countries. However, a recent review of literature has shown that social workers ran into many problems. The problems that social workers run into can be categorized as following: "heavy workload, working with limited resources, stress, exhaustion, forced applications, low wages". The leading problems that social workers face are difficulty of the job, the low levels of satisfaction from the occupation and high levels of exhaustion. Miller (2015) also emphasizes that social workers face a stream of problems throughout their carriers and states that these problems are mostly related to legal and ethical topics.

As emphasized by the body of social work literature, social workers in our country carry out their duties and responsibilities with various difficulties. These difficulties can be summarized as negative working conditions, problems regarding to promotion based on merit, the problem of titles, the inadequacy of wages and problems in occupational relations. These difficulties no doubt lower the quality of the services, but they also create psychological exhaustion and dissatisfaction for social workers and these problems might even lead to quitting processes. Despite all the difficulties that social workers face, the lack of literature on problems of the social workers in Turkey is remarkable. Indeed, during the literature review, no research that takes the occupational problems of the social workers in an empirical and deeper level was found. 
Categorically, howsoever it is known facts that social workers are exposed to very serious problems like frequent changes in social policies, lack of in-service training, political pressures. Besides, the profession is mostly regarded to have a low-status in social aspect. Being a feminine based profession, problem being performed easily by any one and a low-paid profession that performers are unwilling to improve themselves.

Indeed, the economic problems in Turkey have affected the social work profession as well as every other profession and it is observed that social workers' wages are very low and burnout levels of social workers are very high (Iş1khan, 1998; Berkün, 2010). Foregoing problems show that social workers have not reached the position they deserve morally and economically. This situation that the social work profession is in should be corrected, and solutions to problems of social workers are required to be found for future benefits of Turkey as soon as possible. No doubt, this situation requires problems of social workers to be determined relying on their own perceptions in a comprehensive manner. Yet, previously mentioned studies about the social workers' professional problems are very limited in Turkey. Also, conducted studies are based on observational assessments. Moreover, it is seen that there has been no attempt to develop a scale to investigate the perceptions of the social workers regarding their professional problems.

Considering the limited number of studies on social workers' professional problems in Turkey, This study sought to develop a valid and reliable Likert type scale in order to investigate the perceptions of the social workers about their professional problems. Perception is the process of organizing and interpreting acquired sensory information. Many other factors such as attention, learning, motivation, readiness to subject and interest affect can be categorized. In this context, while examining the extent to which social workers perceive their professional problems, the problems will also be determined.

It is expected to provide a data source and to give direction to management, education, wage, promotion policies; social workers' union and social workers' professional associations policies; in-service training policy for the solution of social workers' professional problems found out in this study. Also, it is hoped that it will contribute to the existing national and international literature on this subject.

\section{Method}

\subsection{Participants}

This study was conducted to develop a scale for the purpose of finding out professional problems of social workers within the comparative relational-research model (Karasar, 2000). This research focuses on social workers who are working in social service institutions in Turkey. In accordance with the subject of the research, social workers working in 81 provinces of Turkey in 2014 had reached, 98 social workers in only 24 provinces participated in research. When the distribution to the provinces of social workers are examined, it is seen that the participants work in Istanbul, Ankara, Izmir, Adana, Eskisehir, Trabzon, Samsun, Diyarbakir, Konya, Karaman, Kayseri, Aydin, Hatay, Elazig, Yozgat, Corum, Amasya, Yalova, Kutahya, Duzce, Bolu, Karabuk, Tekirdag, Sakarya. Of the 98, 9 surveys were removed due 
to incomplete or unusable information leaving the total sample of social workers from the twenty-four different institutions at 89. Participants were 89 social workers working in the mentioned cities. Fifty-one participants $(57.30 \%)$ were female and the remaining $38(42.70 \%)$ were male. Fourty-three participants $(48.30 \%)$ were single, fourty-six participants $(51.70 \%)$ were married. Fifty-two participants $(58.43 \%)$ have found their income level sufficient in terms of meeting basic needs, nineteen participants have found their income level sufficient enough for saving money, and eighteen participants have found their income level inadequate. Seventy-five participants $(84.30 \%)$ were satisfied with being social worker, the remaining fourteen participants $(15.70 \%)$ were not satisfied with their job. Eighty-two participants $(92.13 \%)$ accept themselves to be compatible to profession in terms of personal characteristics and remaining seven participants (7.87) view themselves as not compatible to profession in terms of personal characteristics. Nineteen participants $(21.35 \%)$ have positive future expectancy. But seventy participants (78.65\%) don't have confidence for future. It is seen that half of the participants (49.40\%), fourty-four social workers are unionized, fourty-five social workers are not unionized. All of the participants were between ages 22 to 62. Finally, all of the social workers in the sample participated in the study as volunteer.

\subsection{Data Collection}

In this study, the data were collected using a questionnaire consisting of two sections, developed by Karaca and Gökçek Karaca to determine the social workers' professional problems. The first part is the form related to demographic and personal information, consisting of items about the gender, age, marital status, status, managerial positions, the type of institution, provincial aspects, social work experience, branch, income level, satisfaction level of social work, income level sufficiency, future confidence perception, compatibility with the profession in terms of personal characteristics, perceptions syndication. The second part includes 40 expressions related to professional problems of social workers on a 3-point Likert-type scale consisting of 3 choices, from $1=$ Disagree to $3=$ Agree.

In this study, it is tried to develop a valid and reliable scale in order to measure the perceptions of the social workers about their professional problems. In the first stage of the development of the scale (the Professional Problem Perceptions Scale of Social Workers), the literature on the social work profession and its problem was investigated. Then, the measurement instruments on the problems of the social work profession and other professions were reviewed. Then, 20 social workers who work in Eskisehir were asked to write a composition which reflects their emotions, thoughts and behavior related to social work profession and the problems it involves. As a result of literature search and content analysis of the composition, 40 written problem expressions were obtained. In this way, the prepared scale examined by an expert in terms of language. The views of a group of social workers and specialists working in universities were taken for content validity. In line with the reported opinions, the Professional Problem Perceptions Scale of Social Workers has been given as final form.

The Professional Problem Perceptions Scale of Social Workers was administered to 98 social workers in the study group. Nine questionnaires were omitted, because they were not filled 
out according to the instructions.

\subsection{The Analysis of Data}

The research data was analyzed with factor analysis by using the statistical package SPSS. Factor analysis was conducted in order to check the construct validity of the scale. A scale having 17 items consisting of seven factors was developed as a result of the factor analysis. Factor analysis is a statistical data reduction technique used to find latent variables or factors among observed variables. In other words, if research data contains many variables, factor analysis can be used to reduce the number of variables. With factor analysis, a small number of factors can be produced which are capable of explaining the observed variance in a larger number of variables. The reduced factors can also be used for further analysis (Büyüköztürk, 2002).

Reliability coefficients were calculated by applying Cronbach $\alpha$ for each subscale, determined as a result of varimax rotation and for the whole scale.

\subsection{Procedure}

The Professional Problem Perceptions Scale of Social Workers was administered to the social workers at the participating province in 2014. The purpose of the study was explained to the social workers and they were asked to read the instructions. The social workers completed the questionnaires independently in approximately 35 minutes.

\section{Results}

The construct validity of the Professional Problem Perceptions Scale of Social Workers was examined by means of factor analysis. In the factor analysis, the items with a factor load value higher than .30 and item total correlation coefficient higher than .20 are considered (Büyüköztürk, 2002). Having higher variance rates after factor analysis results in a stronger factor structure of the scale (Gorsuch 1974; Lee \& Comrey, 1979). In social sciences, the variance rates changing in the range of $40 \%$ and $60 \%$ are accepted as sufficient (Scherer et al., 1988). According to this criteria, item 18 was extracted from the scale. 22 items to which Principal Components Analysis was applied were collected under eight factors whose eigenvalues are higher than 1.00. Therefore, the Professional Problem Perceptions Scale of Social Workers can be accepted with a maximum of 8 factors. The cumulative variance explained by eight factors is $70.34 \%$. According to the Principal Components Analysis, the eigenvalue of the first factor is 5.19 and the variance it explains is $23.61 \%$. For the second factor the results are 2.46 and $11.18 \%$, for the third factor, 1.65 and $7.50 \%$, for the fourth factor, 1.41 and $6.42 \%$, for the fifth factor, 1.36 and $6.17 \%$, for the sixth factor, 1.28 and $5.81 \%$, for the seventh factor, 1.12 and $5.08 \%$ and the eighth factor, 1.02 and $4.64 \%$, respectively. This finding shows that eight factors determined as important factors explain the majority of cumulative variance in the items and the variance related to the scale. Also it is observed that the 22 items come under the first factor and first factor load values vary between .30 and .66 . The variance of the items in the scale is between .42-.84.

In Principal Components Analysis, the value of Kaiser-Meyer-Olkin (KMO) was found as .70. 


\section{Macrothink}

A KMO test is carried out to inspect the sufficiency of distribution for factor analysis and tests whether partial correlations are small or not. A value of KMO higher than .70 is evaluated as "middle". Also Barlett test result of $501.226(\mathrm{p}<.01)$ indicates that factor analysis is suitable for variables.

As the perceptions of the social workers about their professional problems are determined with eight factors, a rotation process was performed using the varimax technique to find the items having high relations with the factors and to interpret the items easily (Büyüköztürk, 2002). After rotation, items 6, 12, 21, 22, 23, and 26, having high factor loads but collected under seven factors, were extracted from the scale and 17 items remained. Also it is observed that 17 items is collected under seven factors whose eigenvalues are higher than 1.00 and the 17 items come under the first factor and first factor load values vary between .33 and .69 . The variance of items in the scale is between .53 and .83. This finding shows that the Professional Problem Perceptions Scale of Social Workers consists of the items having high relations and this scale measure the structure, defined as the professional problems of social workers. The cumulative variance explained by seven factors is $73.93 \%$. The variance first factor explains is $26.07 \%$, for the second factor it is $13.17 \%$, for the third factor it is $8.54 \%$, for the fourth factor it is $7.62 \%$, for the fifth factor it is $7.519 \%$, for the sixth factor it is $6.00 \%$, seven factor, $5.34 \%$ respectively. This findings shows that the factor construct of The Professional Problem Perceptions Scale of Social Workers is strong. The overall reliability coefficient was .82. These value proves that the scale is reliable.

Table 1 contains the fundamental component analysis results and load values on four factors and item-total correlation factors which were obtained through varimax rotation made to examine the factor structures. 
Table 1. Basic components analysis and varimax rotation results

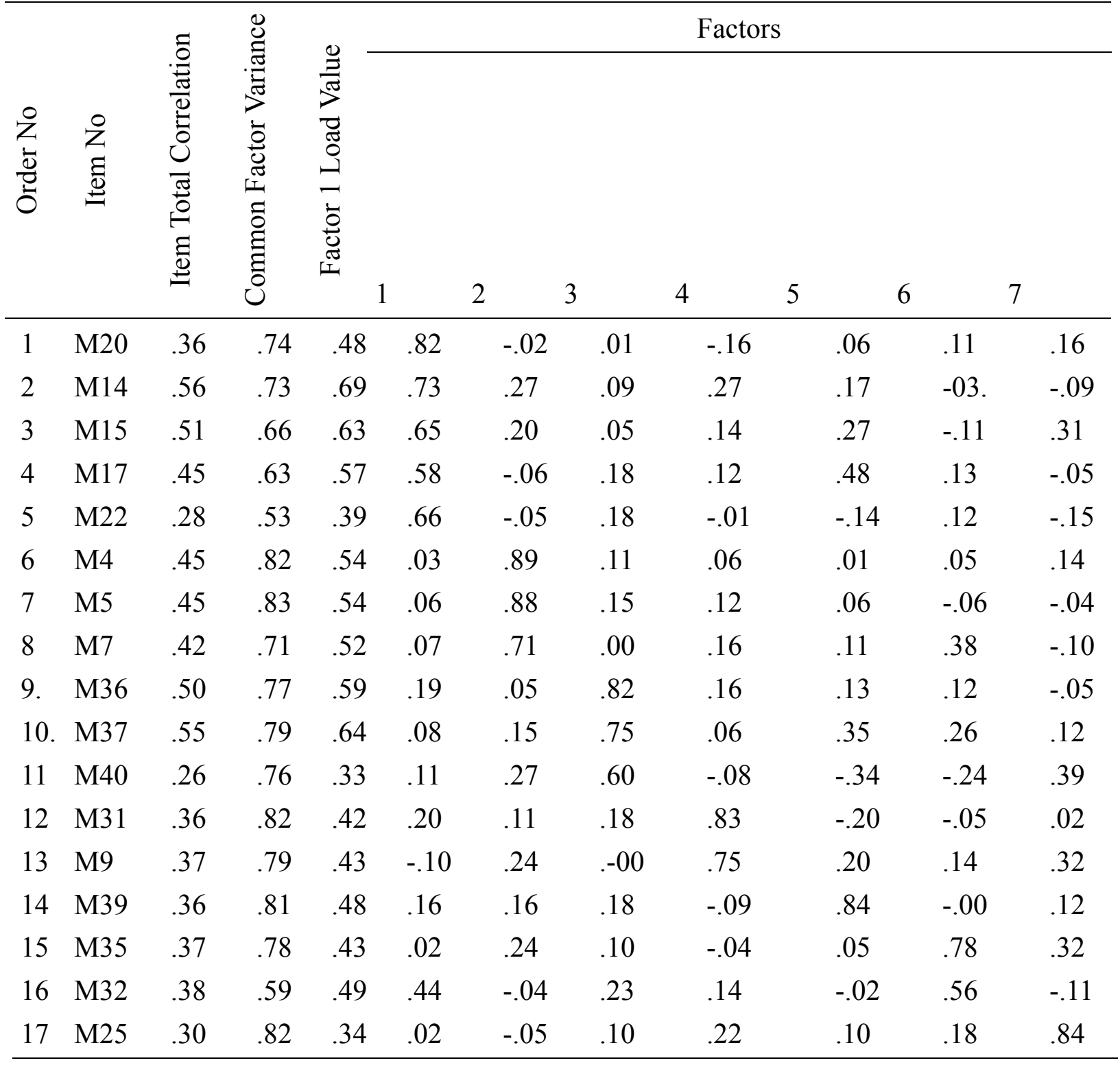

Explained Variance

Total $=73.93 \%$

Factor- $1=26.07 \%$

Factor $-2=13.17 \%$

Factor $-3=8.54 \%$

Factor $-4=7.62 \%$

Factor $-5=7.19 \%$

Factor $-6=6.00 \%$

Factor $-7=5.34 \%$

Cronbach $\alpha=.82$ 


\section{Macrothink}

International Journal of Social Work

ISSN 2332-7278

2016, Vol. 3, No. 1

Factors are named for the meanings that the items include. In the first factor there are 5 items and this factor is named "Working conditions and social rights". The second factor, named "Working method", consists of 3 items. The third factor, named "Professional identity", consists of 3 items. The fourth factor, named "Professional execution conditions", consists of 2 items. The fifth factor, named "Employment and promotion policies", consists of 1 items. The sixth factor, named "Professional organization', consists of 2 items. The seventh factor, named "Vocational integration", consists of 2 items.

Table 2. The Distribution of Items in The Professional Problem Perceptions Scale of Social Workers According to Factors

\begin{tabular}{ll}
\hline Factors & Items \\
\hline 1. Factor: Working Conditions and Social Rights & $1-5$ \\
2. Factor: Working Method & $6-8$ \\
3. Factor: Professional Identity & $9-11$ \\
4. Factor: Professional Execution Conditions & 12,13 \\
5. Factor: Employment and Promotion Policies & 14 \\
6. Factor: Professional Organization & 15,16 \\
7. Factor: Vocational Integration & 25 \\
\hline
\end{tabular}

\section{Discussion and Conclusion}

In this study, it is tried to develop a valid and reliable scale in order to measure the perceptions of the social workers about their professional problems. In the first stage of the development of the scale the literature on the social work profession and its problems were examined. Then, the measurement instruments on the problems of the social work profession and other professions were reviewed. Finally, 27 social workers who work in Eskisehir, Istanbul and Ankara, Turkey in 2014 were asked to write a composition which reflects their emotions, thoughts and behavior related to social work profession and the problems it involves.

In the first stage of the development of the scale, the prepared scale was examined by a specialist in terms of language. The views of a group of social workers and specialists working in universities were taken for content validity. In line with the reported opinions, the Professional Problem Perceptions Scale of Social Workers has been given its final form.

The results of factor analysis showed that the reliability coefficient of the Professional Problem Perceptions Scale of Social Workers the factor construct of which was strong as high at the same time. On the other hand, results of the factor analysis revealed that the seven-factor structure of the Professional Problem Perceptions Scale of Social Workers consisting of 17 items was convenient to explain the relationship between social workers' professional problems and working conditions, wages, environmental conditions, conditions related to execution of the profession, job placement and employment policy, educational 
policy, quality of life and legal regulations. The findings obtained from this study show that the scale is valid and reliable for the data obtained from the study group. According to the results of the research, the social workers current problems can be categorized as 'working conditions and social rights', 'working method', 'professional identity', 'professional execution conditions', 'employment and promotion policies', 'professional organization' and 'vocational integration'. As also stated by Miller, C1lga, Işıkhan and Berkün, all of these problems cause dissatisfaction with the occupation and they also require occupational integration and trake it difficult to solve the problems of the applicants. The fact that these problems show variation pursuant to various social service fields also makes solving the occupational problems of the social workers much more difficult. As also stated by Cilga, overcoming all of these difficulties that social workers in Turkey run into dependent on the development of effective policies made for social workers. In this context, the state and the social parties must take responsibility, and the social workers should also be aware of that responsibility.

When repeating the reliability and validity studies and comparing the analysis it was realized that having similar features in a form including all social workers from different areas of work would also be useful for determining the structural validity. In this regard, a number of studies should be conducted by using the 'the Professional Problem Perceptions Scale of Social Workers' and the findings obtained should be compared with the findings from this research.

This research; which has the goal to determine the professional problems of the social workers can help to create policies that resolving professional problems and making this profession efficient. These researches can also be helpful in guiding employment and social policies towards social workers. It is also hoped that this research is a good addition to the literature for researchers that work on profession conditions and problems to the national \& international literature.

\section{Acknowledgement}

"This study was supported by Anadolu University Scientific Research Projects Commission under the grant no: 1306 S262".

\section{References}

Altunöz (2014), Basic problems of social work profession in turkey. Retrieved June May 20, 2015, from http://www.sosyalhizmetuzmani.org/turkiyedeshmtemelsorunu.htm

Basım, H. N., \& Şeşen, H. (2005). Burnout at Working Life: A Comparative Study on Nurses and Social Workers, Journal of Society and Social Service, 2(16), 57-69.

United Nations. (2005). UNDP human develop report. Retrieved June 20, 2014, from http://www.undp.org.tr/publicationsDocuments/HDR05_complete.pdf

Berkun, S. (2010). The Vocational Challenges That Social Services Experts Exposed to in Their Working Life: The Example of Bursa, Journal of Society and Social Service, 21(1), 99-110. 


\section{Macrothink}

International Journal of Social Work

ISSN 2332-7278 2016, Vol. 3, No. 1

Bulut, I. (2014). About social worker title. Retrieved May 20, 2015, from http://www.sosyalhizmetuzmani.org/sosyal_hizmet_unvani_hakkinda.htm

Büyüköztürk, Ş. (2002). Data analysis handbook for social sciences. Ankara: Pegem A Publishing.

Ceylan, C. (2014). Difficulties faced in professional practice of social workers working in shçek in Samsun province. Retrieved May 20, 2015, from http://www.sosyalhizmetuzmani.org/samsunshu4.htm

C1lga, İ. (2004). Social work as a profession and science in Turkey Ankara: Hacettepe University Social Services College.

State Planning Organization. (2001). Eighth five-year development plan, special expertise report on social services and benefits. Retrieved June 20, 2014, from http://ekutup.dpt.gov.tr/sosyalhi/oik605.pdf

Gorsuch, R. L. (1974). Factor analysis. Philadelphia: Saunders.

Işıkhan, V. (1999). Social Service Organizations and Stress, Journal of Social Service, 1(9) 44-53.

Işıkhan,V. (1998). Job Satisfaction of Social Workers, Journal of Social Service, 1(7) 36-38.

Lee, H. B. ve Comrey, A. L. (1979). Distortions in a Commonly Used Factor Analytic Procedure, Multivariate Behavioral Research, 14, 301-321. http://dx.doi.org/10.1207/s15327906mbr1403_2

Miller, A. (2015). Legal and ethical issues facing social workers. Retrieved October 20, 2015, from http://work.chron.com/legal-ethical-issues-facing-social-workers-21676.html

Scherer, R. F., Wiebe, F. A., Luther, D. C. ve Adams, J. S. (1988). Dimensionality of Coping: Factor Stability Using the Ways of Coping Questionnaire, Psychological Reports, 62, 763-770. http://dx.doi.org/10.2466/pr0.1988.62.3.763 


\section{Ml Macrothink}

\section{Appendix}

Appendix 1. The Professional Problem Perceptions Scale of Social Workers

\section{FIRST PART}

\section{PERSONAL INFORMATIONS, SOCIAL AND ECONOMIC CONDITIONS}

1. Gender: ( ) Female ( ) Male

2. Age:

3. Marital status:

( ) Single

( ) Married

Other

4. Working city:

5. Graduated

university:

6. Graduated

faculty:

7. Social

work

profession

seniority

time:

8. Welfare field you work:
( ) Family and child
( ) Youth
( ) Disabled
( ) Elderly
( ) Women

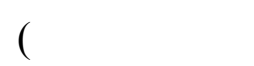

Other

9. Are you in manager position at your workplace? ( ) Yes

( ) No

10. The

amount

of

your wage:

11. Can you subsist with your total income?

( ) Yes

( ) No

12. Are you a member of any trade union?
( ) Yes
( ) No

13. Are you happy with your job?
( ) Yes ( ) No

14. Are you compatible with the profession in terms of personal characteristics?
( ) Yes
( ) No

15 Are you hopeful about your future within your current condition?
( ) Yes
( ) No 


\section{SECOND PART}

The Professional Problem Perceptions Scale of Social Workers

\begin{tabular}{|c|c|c|c|}
\hline \multirow[b]{2}{*}{ Professional Problems Statements } & \multicolumn{3}{|c|}{ Opinions } \\
\hline & Agree & $\begin{array}{l}\text { No } \\
\text { idea }\end{array}$ & Disagree \\
\hline \multicolumn{4}{|l|}{$\begin{array}{l}\text { 1. I think that social workers are working without proper } \\
\text { technical equipments, tools and instruments in terms of } \\
\text { efficient provision of services. }\end{array}$} \\
\hline \multicolumn{4}{|l|}{$\begin{array}{l}\text { 2. I think that social workers are working in inadequate } \\
\text { condition in terms of efficient provision of services. }\end{array}$} \\
\hline \multicolumn{4}{|l|}{$\begin{array}{l}\text { 3. I think that not being provided auxiliary staff even when } \\
\text { necessary to social workers impedes the effective execution of } \\
\text { the service. }\end{array}$} \\
\hline \multicolumn{4}{|l|}{$\begin{array}{l}\text { 4. I think that being forced to work mainly focused on social } \\
\text { aid contrary to working with an occupational focus of social } \\
\text { workers reduces the efficiency of work. }\end{array}$} \\
\hline \multicolumn{4}{|l|}{$\begin{array}{l}\text { 5. I think that being forced to work focusing on short-term or } \\
\text { instantaneous problem solutions of social workers reduces the } \\
\text { efficiency of work. }\end{array}$} \\
\hline \multicolumn{4}{|l|}{$\begin{array}{l}\text { 6. I think that being forced by the executives to do jobs } \\
\text { unrelated to the profession of social workers reduces the } \\
\text { efficiency of work. }\end{array}$} \\
\hline \multicolumn{4}{|l|}{$\begin{array}{l}\text { 7. I think that not working with an expertise focus of social } \\
\text { workers is an important problem in terms of the efficiency. }\end{array}$} \\
\hline \multicolumn{4}{|l|}{ 8. I think that social workers have heavy work load } \\
\hline \multicolumn{4}{|l|}{$\begin{array}{l}\text { 9. I think that being forced to deal with bureaucratic tasks } \\
\text { after working hours of social workers also increases work } \\
\text { load. }\end{array}$} \\
\hline \multicolumn{4}{|l|}{$\begin{array}{l}\text { 10. I think that the social assessment reports prepared by } \\
\text { social workers are not taken into account. }\end{array}$} \\
\hline \multicolumn{4}{|l|}{$\begin{array}{l}\text { 11. I think that the decisions that social workers make are not } \\
\text { respected. }\end{array}$} \\
\hline \multicolumn{4}{|l|}{$\begin{array}{l}\text { 12. I think that social workers are not able to spend enough } \\
\text { time on themselves or their family due to the work load. }\end{array}$} \\
\hline \multicolumn{4}{|l|}{$\begin{array}{l}\text { 13. I think that social workers are not acquiring the value they } \\
\text { deserve due to social work profession's definition. }\end{array}$} \\
\hline 14. I believe that merit is not very important for occupational & & & \\
\hline
\end{tabular}


promotions for social workers

15. I don't think that the given social rights to social workers are inadequate.

16. I think that being evaluated as charity based profession social work don't have obstacle of professionalized.

17. I don't believe that being manager of persons who do not have social work formation is contrary to professional ethics.

18. I think that the excess workload of social workers limit their private lives.

19. I don't belive that social workers are exposed to multifaceted mobbing in their working environment.

20. I believe that wage of social workers is too low compared to their workload.

21. I don't believe that social workers are deprived from opportunities for occupational self development.

22. I think that complicated social work regulations that are inadequate make execution of work difficult for social workers.

23. I don't believe that training given to the social work profession is inadequate.

24. I think that in-service education geared towards occupational development is insufficient

25. I think that no supervisor support when beginning work is a significant lack for social workers

26. I think that executing by different profession groups of social work profession is to increase job dissatisfaction.

27. I think that social workers are exposed to pressure from the executive in terms of execution of the profession.

28. I think that social workers are being threatened by change of duty station.

29. I think that no special laws for protection of rights a significant lack for social workers occurs

30. I think that the complexity of social work legislation makes execution of work difficult for social workers.

31. I think that social workers are insufficient to solve the problems of clients.

32. I don't think that social workers are unsuccessful in 
occupational organization and unity in the context of protecting occupational interests

33. I think that no clear definition for occupational duties and no clear limits for the occupation makes execution of work difficult for social workers.

34. I think that no social service schools of thought or philosophies that would develop the occupation's raising discussion about the title of the profession.

35. I think that no orientation when beginning the work is a significant lack for social workers

36. I don't think that social workers live professional identity issues of social workers.

37. I think that differentation of problems according to their social work area of social workers makes it difficult to solve their professional problems.

38. I don't believe that social workers lose their credibility and social reputation.

39. I don't think that social services intervention of other professionals makes it difficut to engage in social work.

40. I think that social workers violate the rules about the secrecy of their job.

\section{Copyright Disclaimer}

Copyright reserved by the author(s).

This article is an open-access article distributed under the terms and conditions of the Creative Commons Attribution license (http://creativecommons.org/licenses/by/3.0/). 